\title{
Ultrastructural study of spermatogenesis in the Pacific oyster Crassostrea gigas (Bivalvia: Ostreidae) from the Sea of Japan
}

\author{
O.V. Yurchenko, V.I. Radashevsky, A.A. Reunov \\ A.V. Zhirmunsky Institute of Marine Biology, FEB RAS, Vladivostok, 690041, Russia. \\ e-mail: olyurchenko@yandex.ru
}

ABSTRACT: Spermatogenesis in the Pacific oyster Crassostrea gigas from the Sea of Japan, was studied with transmission and scanning electron microscopes. Spermatogonia are characterized by two kinds of nuage-like material (large germinal body-like structure and/or cluster of small globules), cisternae of endoplasmic reticulum and prominent Golgi body that gives rise to occasional proacrosomal vesicles. Spermatocytes contain numerous proacrosomal vesicles, while both kinds of nuage-like material are rarely observed at this stage. A large single acrosomal vesicle is formed by fusion of proacrosomal vesicles in the basal part of each spermatid. After migration to the apical position of the acrosomal vesicle becomes cup-shaped; the round nucleus assumes barrel-like outlines. Part of spermatocytes and spermatids develop with flagellum while some spermatogenic cells are characterized by intracellular axoneme. Spermatozoa have an electron-lucent knob situated on top of the acrosome. This type of knob has never been described earlier in the $C$. gigas and other ostreids. The pattern of $C$. gigas spermatogenesis which includes many ultrastructural features may be used in future comparative studies of sperm development in Ostreidae and other mollusks.

KEY WORDS: Crassostrea gigas, Ostreidae, sperm cells, ultrastructure.

\section{Ультраструктурное исследование сперматогенеза тихоокеанской устрицы Crassostrea gigas (Bivalvia: Ostreidae), обитающей в Японском море}

\author{
О.В. Юрченко, В.И. Радашевский, А.А. Реунов
}

Институт биологии моря имени А.В. Жирмунского ДВО РАН, Владивосток, 690041, Россия. e-mail: olyurchenko@yandex.ru

РЕЗЮМЕ: Методами сканирующей и трансмиссионной электронной микроскопии исследован сперматогенез тихоокеанской устрицы Crassostrea gigas из Японского моря. Сперматогонии содержат два типа материала «нуаж» (герминальное тельце и/ или скопление мелких гранул), цистерны эндоплазматического ретикулума и диктиосомы комплекса Гольджи, формирующие проакросомные везикулы. В сперматоцитах отмечены многочисленные проакросомные везикулы, материал «нуаж» присутствует значительно реже. В базальной части сперматид путем слияния проакросомных везикул формируется одна крупная акросомная гранула. После того, как акросомная гранула занимает апикальное положение, она становится чашевидной, а ядро 
сперматиды - бочонковидным. Часть сперматоцитов и сперматид развиваются со жгутиком, часть клеток вместо жгутика имеют только внутриклеточную аксонему. В сперматидах появляется электронно-прозрачный пузырек, расположенный на вершине акросомной гранулы. Этот пузырек остается характерной деталью строения сперматозоида, ранее неописанной ни у C. gigas, ни у других видов остреид. Паттерн сперматогенеза C. gigas, который включает в себя большое количество ультраструктурных признаков, может быть использован для будущих сравнительных исследований развития сперматогенных клеток у Ostreidae и других моллюсков.

КЛЮЧЕВЫЕ СЛОВА: Crassostrea gigas, Ostreidae, сперматогенные клетки, ультраструктура.

\section{Introduction}

It is known that the general principle of comparative spermatology has developed from the view of Kolliker who wrote that the animal sperm varies within narrow limits (Afzelius, 1984) to the statement of Retzius who assumed the infinite structural diversity of metazoan sperm and suggested impossibility of the existence of even two species with similar sperm morphology (Retzius, 1904; Franzen, 1956). Thus, Retzius established a principle of species specificity of spermatozoa and showed that sperm morphology is a very reliable taxonomic feature. Since no coincidence in the morphology of spermatozoa in various species of metazoan animals has been found, the Retzius' conclusion has not been refuted until now.

However, data obtained by different researchers during the last forty years allow suspecting sperm uniformity in some species of the family Ostreidae. Indeed, it was reported that mature spermatozoa are similar in various ostreids in having a cup-shaped acrosome, subacrosomal material with an axial rod, a barrel-shaped nucleus, and four spherical mitochondria (Daniels et al., 1971; Brandriff et al., 1978; Osanai, Kyozuka, 1982; O Foighil, 1989; Healy, Lester, 1991; Bozzo et al., 1993; Sousa, Oliveira, 1994a; Li et al., 2000; Dong et al., 2005; Drozdov et al., 2009). Comparing the sperm morphology in different oyster species Gwo and co-authors (1996) suggested that the size and shape of a nucleus, an acrosome and mitochondria are specific in ostreid spermatozoa and can be used to differentiate species. However, they did not present reliable statistic data and it remains uncertain whether the reported differences were caused by uncertainty of measurements or they reflect real morphological differences among the species.

The ultrastructural features of spermatogenesis have been studied for several ostreid species. It has been shown that Ostrea edulis Linnaeus, 1758, Crassostrea angulata Lamarck, 1819, and Crassostrea virginica Gmelin, 1791 have basically similar spermatogenesis: spermatogonia and primary spermatocytes contain characteristic so-called nuage-like material, the formation of an acrosome begins with the synthesis of proacrosomal vesicles by the Golgi complex prior to spermiogenesis, the proacrosomal vesicles are fused in the presumptive basal part of the spermatid and the formed acrosomal vesicle migrates from this area to the apex of the cell where it forms the acrosome (Sousa, Oliveira, 1994a; Eckelbarger, Davis, 1996). It seems that spermatogenic cells as well as spermatozoa do not have any differences between oyster species.

The purpose of the present paper is to form a pattern of sperm development in the Pacific oyster Crassostrea gigas Thunberg, 1793, the species, which has been introduced worldwide for commercial cultivation (Ruesink et al., 2005) and widely used in monitoring assays. The early spermatogenesis of $C$. gigas from the Atlantic Ocean (France) was recently described by Franco and co-authors (2008). They gave a detailed description of the size characteristics and chro- 
matin state in spermatogonia and spermatocytes but other features of early spermatogenic cells and spermiogenesis remain poorly known. In our opinion, a study should be done through the finding of some crucial signs of oyster spermatogenesis and comparison of those among the various species of Ostreidae.

\section{Materials and methods}

Mature oysters $C$. gigas were collected by SCUBA divers in the estuary situated in the inner part of Vostok Bay $\left(42^{\circ} 53^{\prime} 37.08^{\prime \prime} \mathrm{N}\right.$, $132^{\circ} 44^{\prime} 02.45^{\prime \prime} \mathrm{E}$ ), Peter the Great Bay of the Sea of Japan, in early June, 2005.

\section{Transmission electron microscopy}

Gonads of five males were fixed in $2.5 \%$ glutaraldehyde (Sigma) in $0.1 \mathrm{M}$ cacodylate buffer (pH 7.5), with $21 \mathrm{mg} / \mathrm{ml} \mathrm{NaCl}$ added, for $2 \mathrm{~h}$ at $4^{\circ} \mathrm{C}$. Specimens were then rinsed in buffer (changed several times), post-fixed for $2 \mathrm{~h}$ with $2 \%$ osmium tetroxide prepared in the same buffer and then washed in buffer before dehydration. After dehydration in a graded ethanol series and acetone, specimens were embedded in Spurr resin (Spurr, EMS). Semi- and ultrathin sections were made using a Leica UC6 ultramicrotome. Semi-thin sections were stained with methylene-blue and examined with a Leica DM4500 B light microscope. Images were taken by a Leica DFC300 FX digital camera. Ultrathin sections were stained with $2 \%$ alcoholic uranyl acetate and aqueous lead citrate, and viewed with JEOL JEM 100 S and Zeiss Libra 120 transmission electron microscopes.

\section{Scanning electron microscopy}

Suspension of sperm cells from dissected gonads was dissolved 1:100 with filtered sea water and placed on nucleapore filters coated with poly-l-lysine hydrobromide (MP Biomedicals Inc). Spermatozoa on the filters were fixed and dehydrated as described above in the TEM procedure, and then critical point dried in carbon dioxide, coated with gold and viewed with a Zeiss LEO 430 scanning electron microscope.

\section{Results}

The sperm cells in the testes of mature males were orderly arranged in acini in such a way that spermatogonia were situated near the inner wall of each acinus, mature spermatozoa occupied the center of the acinus lumen, and spermatocytes and spermatids were situated in between them (Fig 1A).

The spermatogonia contained single oval nuclei about $3.9 \times 4.3 \mu \mathrm{m}$ along short and long axes, respectively (see below in the nucleus descriptions), and patches of electron-dense chromatin scattered in the nucleoplasm and nucleolus (Fig. 1B). Two major kinds of electron-dense non-membranous material or nuage were distinguished in the cytoplasm at this stage (Fig. 1C). One kind was present as variations of a large germinal body-like structure (Fig. 1 D, E) and another as a cluster of small globules (Fig. 1F). The cisternae of the rough endoplasmic reticulum were frequently seen in spermatogonial cytoplasm (Fig. 1F). Besides, the Golgi body forming electron-dense vesicles was also present (Fig. $1 \mathrm{G}, \mathrm{H})$. The spermatogonia were connected by both intercellular bridges (Fig. 1H) and desmosome-like junctions (Fig. 1I).

The primary spermatocytes withround to slightly oval nuclei about $3.6 \times 4.1 \mu \mathrm{m}$ in size had characteristic synaptonemal complexes at the pachytene stage (Fig. 2A). The spermatocytes were connected by intercellular bridges and had a number of electron-dense vesicles distributed in the cytoplasm (Fig. 2B). The nuage appeared mainly a cluster of small globules was noticed in the cytoplasm rarely (Fig. 2C and inset). The secondary spermatocytes were similar in the set of organelles to the primary spermatocytes but had smaller nuclei, about $2.7 \times 3.3 \mu \mathrm{m}$ in size. Additionally, these spermatocytes usually had not any nuage material. Both the primary and secondary spermatocytes were flagellate cells (Fig. 2D). The basal body of the flagellum comprised two centrioles situated perpendicular to each other near the cell membrane (Fig. 2E). Apart from spermatocytes with flagellum (Fig. 2D), the spermatocytes with intracellular axoneme were found (Fig. 2F). 

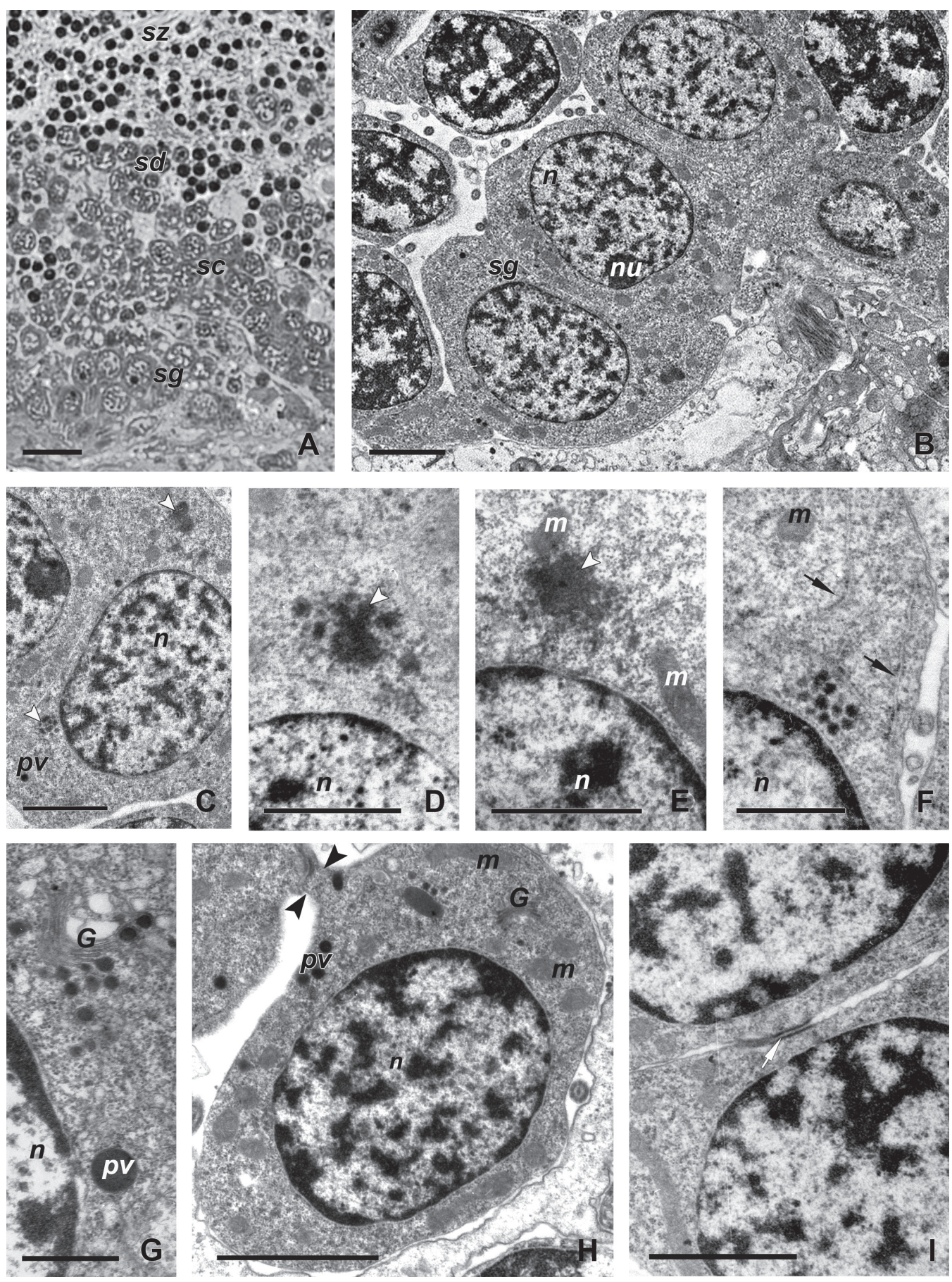
The early spermatids had nuclei with size about $2.5 \times 3.1 \mu \mathrm{m}$ and more condensed chromatin than in the nuclei of spermatocytes. Proacrosomal vesicles were concentrated in the basal area of each cell together with mitochondria (Fig. 3A). After the fusion of proacrosomal vesicles, the formed acrosomal vesicle was located among mitochondria (Fig. 3B) but then moved to the lateral part of the spermatid (Fig. $3 \mathrm{C})$. An electron-lucent knob $(0.1-0.15 \mu \mathrm{m}$ in diameter) appeared on top of the acrosomal vesicle, beneath the cell membrane (Fig. 3D, E). As the cross section shows, a mitochondrial collar, consisting of five to six mitochondria, formed around the centrioles (Fig. 3F). The late spermatids had nuclei about $2.2 \times 2.7 \mu \mathrm{m}$ in size and contained electron-dense chromatin with small electron-lucent areas (Fig. 3G). At this stage the acrosomal vesicle was situated in the apical part of the cell (Fig. 3G). In the course of spermiogenesis the basal part of the acrosomal vesicle became concave and formed invagination filled with flaked material (Fig. 3H). Progressive invagination of both the acrosomal vesicle and the nucleus resulted in the formation of a subacrosomal space. An axial rod appeared in the subacrosomal space (Fig. 3I). At the final stage of the spermatid maturation, small amounts of flaked material were scattered in the nucleus at various distances from the subacrosomal space (Fig. 3J-M). Spermatids with flagellum were typical (Fig. 3C) but cells with an intracellular axoneme were also present in the acini (Fig. 3G).

Each spermatozoon had a barrel-shaped head (Fig. 4A) about $2.5 \mu \mathrm{m}$ long and $2.1 \mu \mathrm{m}$ wide, composed of a cup-like acrosome and electrondense nucleus (Fig. 4B). An electron-lucent knob was situated on top of the acrosome (Fig. $4 \mathrm{~A}, \mathrm{~B}$ ) and they were about $0.7 \mu \mathrm{m}$ long together. The nucleus was $1.2 \mu \mathrm{m}$ long and $1.9 \mu \mathrm{m}$ wide and had an anterior fossa extending through the middle part and filled with flaked material (Fig. 4B). An axial rod extended from the basal part of the acrosome to the posterior part of the nuclear fossa (Fig. 4B). The midpiece consisted of four spherical mitochondria (Fig. 4C) and the basal body of the flagellum composed of the proximal and distal centrioles (Fig. 4B). The distal centriole had nine radially arranged satellite fibers (Fig. 4D). The flagellum had typical $9+2$ pattern of microtubules.

\section{Discussion}

Our data and those previously obtained by Franco and co-authors (2008) enable us to form a pattern of spermatogenesis in C. gigas and compare it with other oysters. The characteristic

Fig. 1. Spermatogonia in the Pacific oyster Crassostrea gigas.

A — fragment of acinus showing developing spermatogenic cells (light microscopy); B-I — spermatogonia (TEM): B - outer part of acinus with spermatogonia and spermatocytes; C - spermatogonium with two kinds of nuage (arrowheads); D, E - two variations of nuage presented as large germinal body-like structures (arrowheads); F spermatogonium containing cisternae of the RER (arrows) and nuage presented as a cluster of small globules; G dictiosomes of the Golgi body with electron dense substance morphologically similar to proacrosomal vesicle content; $\mathrm{H}$ - proacrosomal vesicles in the cytoplasm (arrowheads point at intercellular bridge); I - spermatogonia joined by desmosome-like junction (arrow). Abbreviations: $G-$ Golgi body, $m-$ mitochondrion, $n-$ nucleus, $p v-$ proacrosomal vesicle, $s c$ - spermatocyte, $s d-$ spermatid, $s g$ - spermatogonium, $s z-$ spermatozoon. Scale bars: $\mathrm{A}-10 \mu \mathrm{m} ; \mathrm{B}, \mathrm{C}, \mathrm{H}, \mathrm{I}-2 \mu \mathrm{m} ; \mathrm{D}-\mathrm{F}-1 \mu \mathrm{m} ; \mathrm{G}-0.5 \mu \mathrm{m}$.

Рис. 1. Сперматогонии тихоокеанской устрицы Crassostrea gigas.

A - фрагмент ацинуса с развивающимися сперматогенными клетками (световая микроскопия); B-I - сперматогонии (ТЭМ): В - внешний участок ацинуса со сперматогониями и сперматоцитами; С - сперматогоний содержащий нуаж двух типов (короткие стрелки); D, E - два варианта организации нуаж, представленного крупным герминальным «тельцем» (короткие стрелки); F — цистерны ШЭР (длинные стрелки) и нуаж в виде скопления мелких гранул; G - диктиосомы комплекса Гольджи, содержащие электроноплотный материал, морфологически схожий с содержимым проакросомных гранул; Н - проакросомные гранулы в цитоплазме. Короткие стрелки указывают на межклеточный мостик; I — сперматогонии, соединенные десмосомоподобным контактом (длинная стрелка). Обозначения: $G$ - диктиосомы комплекса Гольджи, $m$ - митохондрия, $n-$ ядро, $p v$ - проакросомные гранулы, $s c-$ сперматоцит, $s d-$ сперматида, $s g-$ сперматогоний, $s z-$ сперматозоид. Масштабы: A - 10 мкм, B, C, H, I - 2 мкм, D-F - 1 мкм, G - 0,5 мкм. 

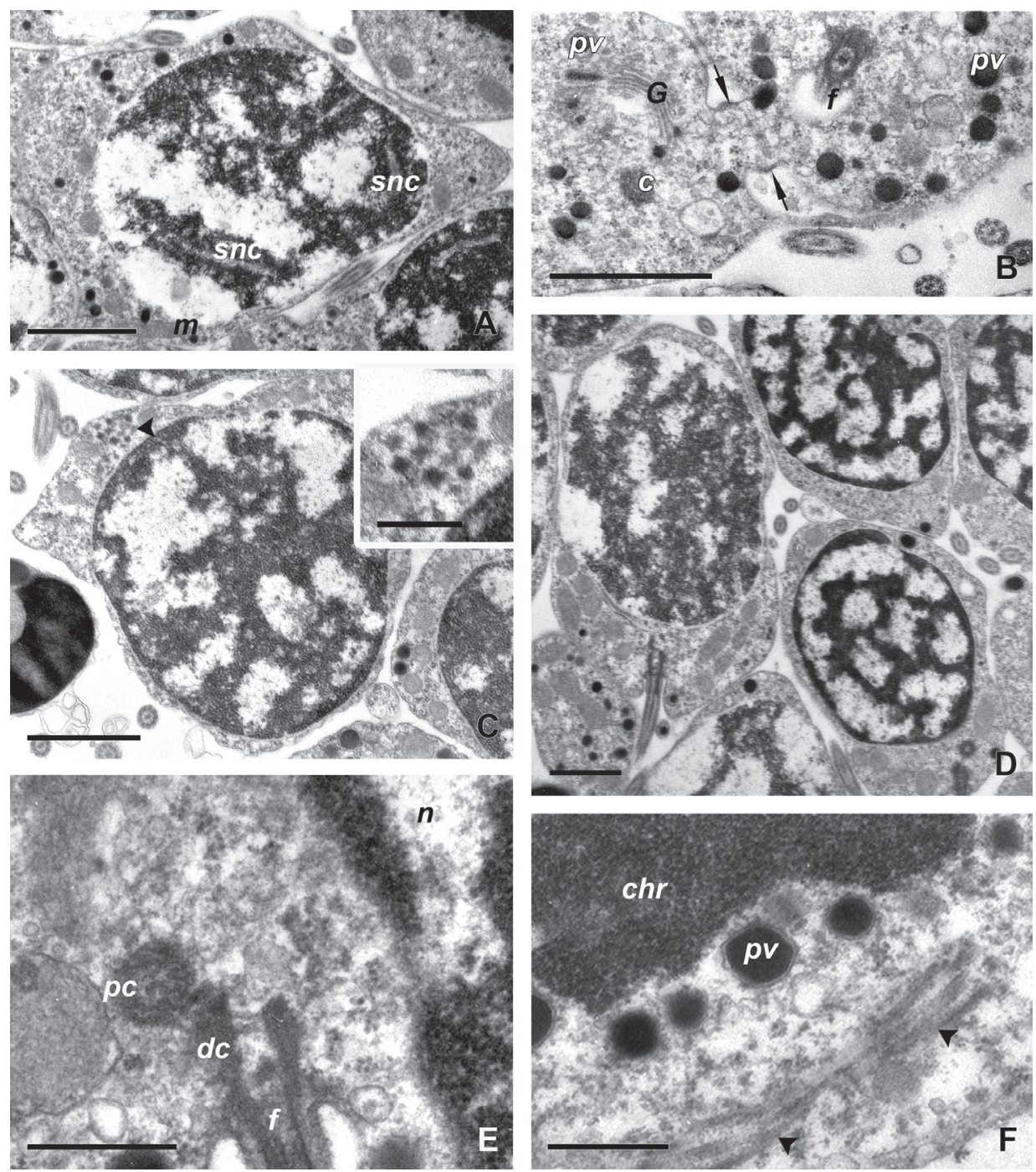

Fig. 2. Spermatocytes in the Pacific oyster Crassostrea gigas (TEM).

A - primary spermatocyte; B - cytoplasmic components of primary spermatocytes (the intercellular bridge is indicated by arrows); $\mathrm{C}$ - spermatocyte with nuage (arrowhead); inset - higher magnification of nuage; D - flagellate spermatocytes; E - two centrioles perpendicular to each other located near the cell membrane; F - dividing spermatocyte with inner axoneme (arrowheads), chromatin is surrounded by proacrosomal vesicles. Abbreviations: $c-$ centriole, $c h r$ - chromatin, $d c$ - distal centriole, $f$ - flagellum, $G$ - Golgi body, $m$ - mitochondrion, $n$ - nucleus, $p v-$ proacrosomal vesicle, $p c-$ proximal centriole, $s n c$ - synaptonemal complex. Scale bars: A-D - $1.5 \mu \mathrm{m}, \mathrm{E}$, $\mathrm{F}-0.5 \mu \mathrm{m}$, inset $-0.3 \mu \mathrm{m}$.

Рис. 2. Сперматоциты тихоокеанской устрицы Crassostrea gigas (ТЭМ).

А - первичный сперматоцит; В - содержимое цитоплазмы первичных сперматоцитов. Длинные стрелки указывают на межклеточный мостик; $\mathrm{C}$ - сперматоцит с материалом нуаж (короткая стрелка); врезка — нуаж увеличено; D — жгутиковые сперматоциты; Е — две перпендикулярные друг другу центриоли, расположенные вблизи плазматической мембраны; $\mathrm{F}$ - делящийся сперматоцит с внутренней аксонемой (короткие стрелки). Проакросомные везикулы расположены вокруг хроматина. Обозначения: $c$ - центриоль, $c h r-$ хроматин, $d c-$ дистальная центриоль, $f$ - жгутик, $G$ - диктиосомы комплекса Гольджи, $m-$ митохондрия, $n-$ ядро, $p v-$ проакросомные гранулы, $p c$ - проксимальная центриоль, $s n c$ - синаптонемальный комплекс. Масштабы: А$\mathrm{D}-1,5$ мкм, $\mathrm{E}, \mathrm{F}-0,5$ мкм, inset $-0,3$ мкм. 
feature of spermatogonia in C. gigas (Fig. 5A) is the presence of nuage which seems to be a distinct marker of the metazoan germ cell lineage (Eddy, 1975; Ikenishi, 1998; Extavour, Akam, 2003). This structure has been described or merely illustrated in various mollusks. In some species only one kind of nuage was noticed (Sousa et al., 1989; Sousa, Oliveira, 1994a, b; Erkan, Sousa, 2002), whereas in some mollusks two patterns of nuage material were found (Hodgson et al., 1990; Erkan, Sousa, 2001, 2002).

Two kinds of nuage such as the "fragmented smaller bodies" and "homogeneous body" were also described in the spermatogonia of the Atlantic population of C. gigas (Franco et al., 2008). Similar structures that we define as the "large germinal body-like structure" (n1) and the "cluster of small globules" (n2) were observed in the Pacific population of the species (Fig. 5A). Though only one kind of nuage reported in C. angulata and Ostrea edulis (Sousa, Oliveira, 1994a) and has not been described in C. virginica (Eckelbarger, Davis, 1996), the dual pattern of nuage is likely to be found in these species.

Another phenomenon is the presence of proacrosomal vesicles in spermatogonia and spermatocytes (Fig. 5A, B). Early appearance of proacrosomal vesicles in spermatogonia has been described for some invertebrates, including bivalves (Hodgson, Bernard, 1986; Reunov, Drozdov, 1987; Eckelbarger et al., 1990; Reunov, Hodgson, 1994). In the Pacific population of $C$. gigas, the first proacrosomal vesicles were found at spermatogonial stage, while in the Atlantic population of $C$. gigas the proacrosomal vesicles were described from the secondary spermatocytal stage (Franco et al., 2008). Taking into account the early development of the proacrosomal vesicles in spermatogonia of $C$. angulata and O. edulis (Sousa, Oliveira, 1994a) we suggest that presence of proacrosomal vesicles in spermatogonia might be found in other oyster species with intensive study and this phenomenon may be common for the oysters.

In the Pacific $C$. gigas the primary spermatocytes were flagellate cells (Fig. 5B). The same phenomenon was recorded for C. angulata (Sousa, Oliveira, 1994a), while in C. virginica and the Atlantic $C$. gigas (according to illustrations presented by authors (Eckelbarger, Davis, 1996; Franco et al., 2008) the flagellum appears only at spermatid stage. Certain conclusion concerning these alternative versions can be made only after careful examination of the flagellum appearance in spermatogenic cells in different oyster species.

It was shown in the present work that in an acinus of the Pacific $C$. gigas the spermatocytes and spermatids were represented by cells with flagellum (Fig. 5C, D, E) as well as cells with intracellular axoneme (Fig. 5C', D', E'). The intracellular axoneme was noticed in the spermatids of the Atlantic C. gigas oysters (Franco et al., 2008) but was not mentioned for other oyster species. However, among mollusks the inner axoneme was reported in the spermatogenic cells of the cockle Anadara granosa (Suwanjarat, 1999), and the green-lipped mussel Perna viridis (Reunov et al., 1999). Besides, they are known for four species of sea urchins (Eckelbarger et al., 1989; Au et al., 1998, 1999). For the sea urchin Anthocidaris crassispina the origin of "inner" axoneme was suggested by Au and coauthors (1998) as a result of different flagellum differentiation. During cell division, the maternal pair of centrioles remains associated with the tail, while the daughter centrioles migrate to the opposite pole of the cell and give rise to an intracellular axoneme. The same reason is conceivable for mollusks including oysters and further research is needed to clarify whether inner axoneme is typical for Ostreidae species.

Spermiogenesis is the most demonstrative process with dynamic transformation of nucleus and all cytoplasmic organelles. Among available reports concerning spermatogenic cell ultrastructure in C. gigas (Bozzo et al., 1993; Franco et al., 2008), the description of spermatid stage/stages is sketchy; furthermore, early spermatids of C. gigas have never been characterized. However, spermiogenesis shows characteristic features of cell morphogenesis and may be used for interspecies comparison. As we have shown for Pacific C. gigas, at early 

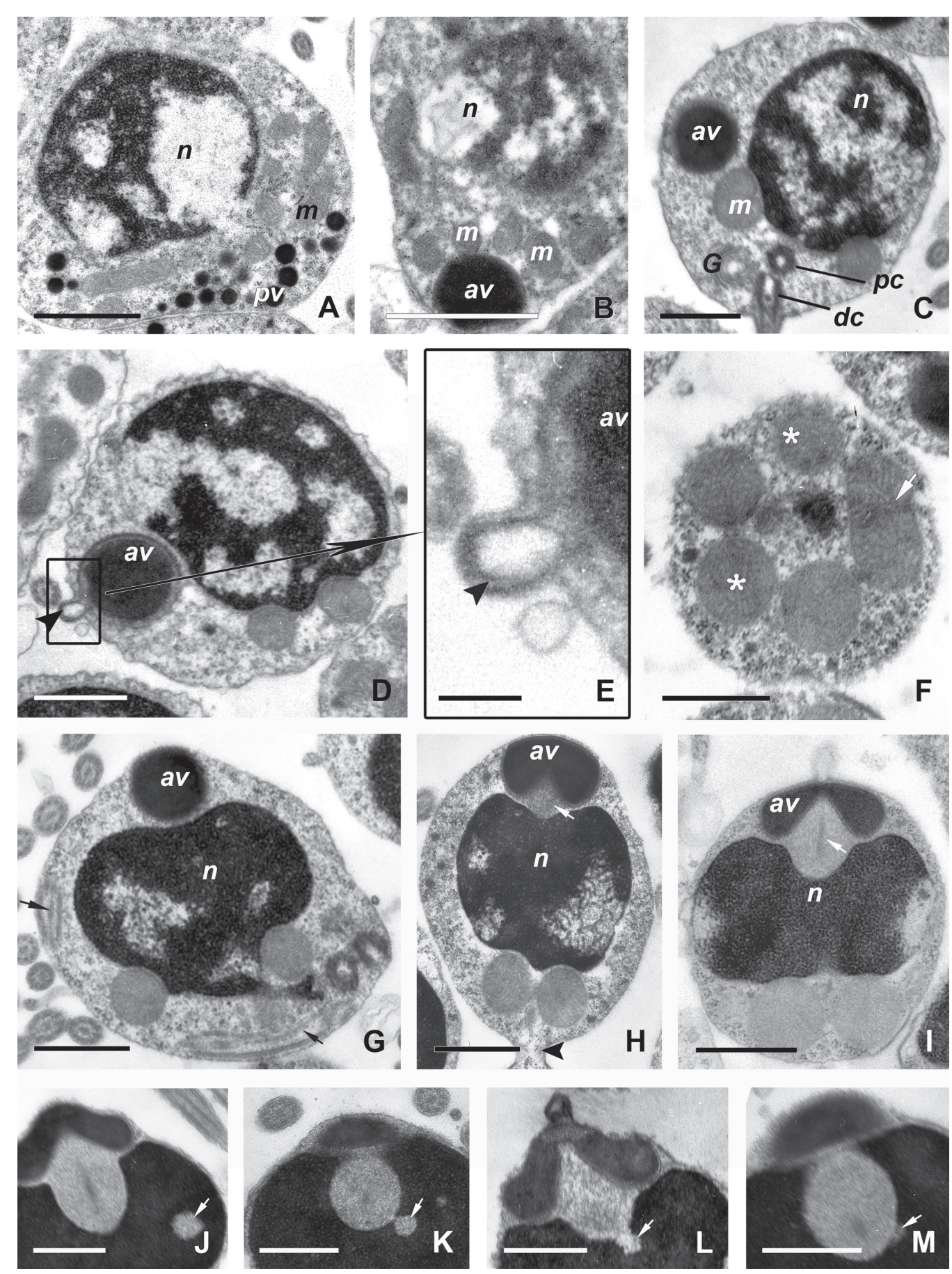
spermatid stage the cytoplasmic organelles demonstrate obviously ordered distribution defining future basal and apical parts of the cell (Fig. 5D, D'). In middle spermatids, the proacrosomal vesicles fuse into a large acrosomal vesicle (5E, E') which afterwards migrates to the apical area of the cell. As soon as the acrosomal vesicle is in this area, its shape gradually transforms from rounded to cupshaped (Fig. 5F, G). The acrosomal vesicle formation is accompanied by the development of a small terminal electron-lucent knob situated on the top of it (Fig. 5E, E'-H).

The development and morphology of the acrosome in C. gigas, as described in the present study, appears similar to previous reports (Bozzo et al., 1993; Gwo et al., 1996; Dong et al., 2005; Drozdov et al., 2009) but differs from them in the presence of the terminal electronlucent knob. The consistent distal position of this knob on the acrosomal vesicle and common movement of both structures to the apical area of spermatozoa, as observed in a series of cells in the present study, exclude interpretation of this structure as an artifact. The function of this knob is unknown, but its overacrosomal position suggests its involvement in the process of fertilization. This structure is likely to have been overlooked in previous investigations of $C$. gigas and other oysters due to possible absence of strict anterior-posterior section and the data obtained with scanning electron microscope. At the same time, if the electron-lucent knob is really absent in the sperm of $C$. gigas from the Atlantic population and other oyster species, it may actually be a specific feature of the Pacific population of $C$. gigas.

The studies of the oyster spermiogenesis show that the presence of subacrosomal material located between the acrosomal vesicle and nucleus is the common feature of late spermatids and spermatozoa of all studied Ostreidae (Bozzo et al., 1993; Sousa, Oliveira, 1994a; Eckelbarger, Davis, 1996). However, the ways

Fig. 3. Spermatids in the Pacific oyster Crassostrea gigas (TEM).

A - early spermatid with proacrosomal vesicles and mitochondria on one pole of the cell; B — middle spermatid with formed acrosomal vesicle; $\mathrm{C}$ - flagellated middle spermatid with acrosomal vesicle in the basal position; D — middle spermatid with acrosomal vesicle associated with electron-lucent knob (arrowhead) in the midway position; E electron-lucent knob (higher magnification) (arrowhead); F — late spermatid containing single rounded mitochondria (asterisks) and fusing mitochondria (arrow) in the basal part of the cell; G - late spermatid with an inner axoneme (arrows) and a spherical acrosomal vesicle in the apical position; $\mathrm{H}$ - late spermatid with invaginations on basal part of acrosomal vesicle and on apical part of the nucleus (subacrosomal space pointed by arrow, intercellular bridge is indicated by the arrowhead); I - late spermatid with barrel-shaped nucleus and cup-like acrosome (axial rod inside the subacrosomal space is indicated by the arrow); J-M - nuclei containing small amount of flaked substance (arrows). Abbreviations: $a$ - acrosome, $a v$ - acrosomal vesicle, $d c$ - distal centriole, $G$ - Golgi body, $m$ - mitochondrion, $n$ - nucleus, $p c$ - proximal centriole, $p v-$ proacrosomal vesicle. Scale bars: A $-2 \mu \mathrm{m}, \mathrm{B}-\mathrm{G}, \mathrm{F}-\mathrm{I}-1 \mu \mathrm{m}, \mathrm{J}-\mathrm{M}-$ $0.5 \mu \mathrm{m}, \mathrm{E}-0.2 \mu \mathrm{m}$.

Рис. 3. Сперматиды тихоокеанской устрицы Crassostrea gigas (ТЭМ).

А - ранняя сперматида, содержащая проакросомные везикулы и митохондрии на одном полюсе; В - средняя сперматида со сформированной акросомной гранулой; C - средняя сперматида с акросомной гранулой в базальном положении и жгутиком; D - средняя сперматида с акросомной гранулой и электронопрозрачным пузырьком (короткая стрелка) в положении между базальным и апикальным полюсами клетки; Е-электронопрозрачный пузырек (большее увеличение) (короткая стрелка); F - базальная часть поздней сперматиды, содержащая одиночные округлые (звездочки) и сливающиеся (длинная стрелка) митохондрии; $\mathrm{G}$ - поздняя сперматида с внутренней аксонемой (длинные стрелки) и сферической акросомной везикулой в апикальном положении; $\mathrm{H}$ - поздняя сперматида с инвагинациями базальной части акросомной гранулы и апикальной части ядра. Длинная стрелка указывает на субакросомное пространство, короткие стрелки указывают на межклеточный мостик; I - поздняя сперматида с бочонковидным ядром и чашеподобной акросомой (осевой стержень внутри субакросомного пространства отмечен длинной стрелкой); J-M - ядра, содержащие небольшое количество хлопьевидного вещества (длинные стрелки). Обозначения: $a$ - акросома, $a v-$ акросомная гранула, $d c$ - дистальная центриоль, $G$ - диктиосомы комплекса Гольджи, $m-$ митохондрия, $n-$ ядро, $p c-$ проксимальная центриоль, $p v-$ проакросомная везикула. Масштабы: А - 2 мкм, B-G, F-I - 1 мкм, J-M - 0,5 мкм, Е-0,2 мкм. 

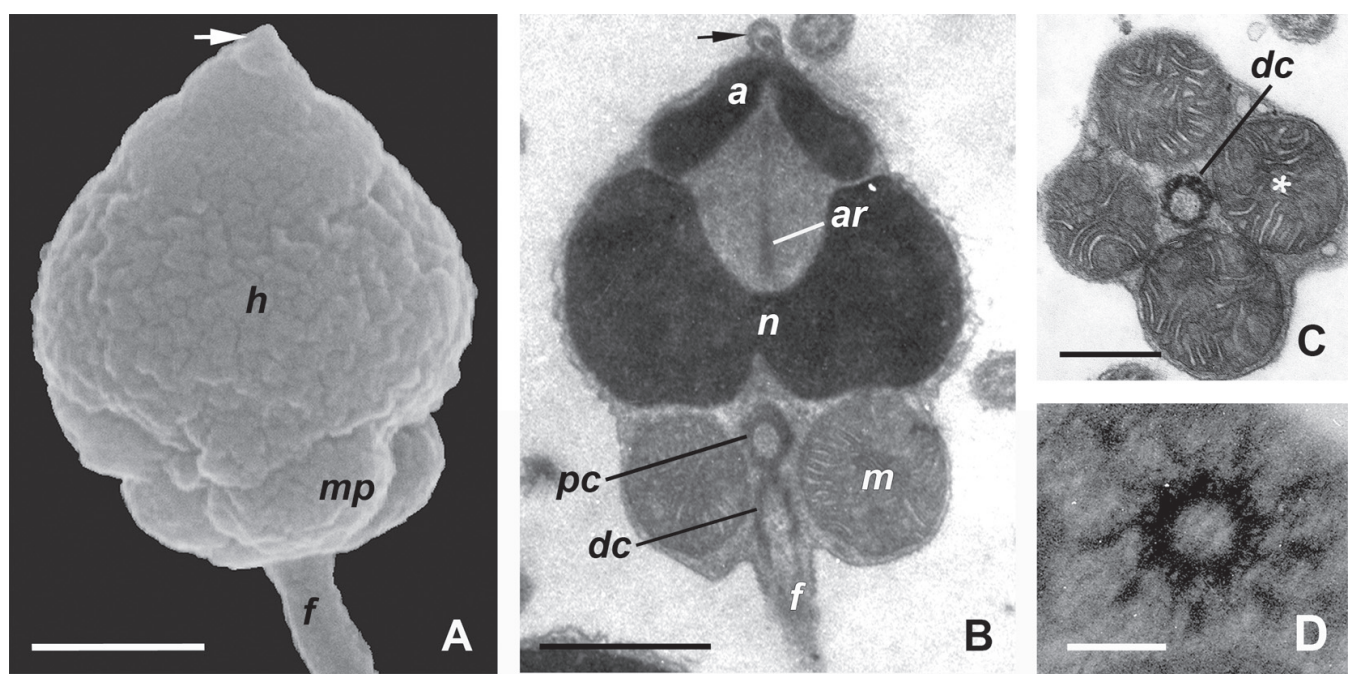

Fig. 4. Spermatozoa in the Pacific oyster Crassostrea gigas by SEM (A) and TEM (B-D).

A - overview of mature spermatozoon; B - mature sperm (terminal electron-lucent knob is indicated by the arrow); $\mathrm{C}$ - midpiece of the spermatozoon showing distal centriole surrounded by four mitochondria (asterisk); D - distal centriole with nine satellite fibers. Abbreviations: $a$ - acrosome, $a r$ - axial rod, $d c$ - distal centriole, $f$ - flagellum, $h$ - sperm head, $m-$ mitochondrion, $m p-$ midpiece, $n$ - nucleus, $p c-$ proximal centriole. Scale bars: A, B $1 \mu \mathrm{m}, \mathrm{C}-0.5 \mu \mathrm{m}, \mathrm{D}-0.2 \mu \mathrm{m}$.

Рис. 4. Сперматозоиды тихоокеанской устрицы Crassostrea gigas по данным CЭМ (А) и ТЭМ (B-D). A - общий вид зрелого сперматозоида (СЭМ); В - зрелый сперматозоид (терминальный электронопрозрачный пузырек обозначен длинной стрелкой); C — средняя часть сперматозоида - дистальная центриоль, окруженная четырьмя митохондриями (звездочка); D - дистальная центриоль с девятью вспомогательными нитями. Обозначения: $a$ - акросома, $a r-$ осевой стержень, $d c-$ дистальная центриоль, $f-$ жгутик, $h-$ головка сперматозоида, $m$ - митохондрия, $m p-$ средняя часть, $n-$ ядро, $p c$ - проксимальная центриоль. Масштабы: $\mathrm{A}, \mathrm{B}-1$ мкм, $\mathrm{C}-0,5$ мкм, $\mathrm{D}-0,2$ мкм.

Fig. 5. Scheme of spermatogenesis in the Pacific oyster Crassostrea gigas.

A - spermatogonium; B - primary spermatocyte; C - secondary spermatocyte with flagellum; C' - secondary spermatocyte with inner axoneme; D - early spermatid with flagellum; D' - early spermatid with inner axoneme; E - middle spermatid with flagellum; E' - middle spermatid with inner axoneme; F - late spermatid; G - late spermatid; $\mathrm{H}$ - spermatozoon. Abbreviations: $a$ - acrosome, $a r$ - axial rod, $a v$ - acrosomal vesicle, $d c$ - distal centriole, $f$ - flagellum, $G$ - Golgi body, iax - intracellular axoneme, $k$ - knob, $m$ - mitochondrion, $n$ - nucleus; $n 1$ - nuage presented as large germinal body-like structure, $n 2$ - nuage presented as cluster of small globules, $n l$ nuclear lacunae, $p c$ - proximal centriole, $p v$ - proacrosomal vesicle, rer - rough endoplasmic reticulum, sas subacrosomal substance, snc - synaptonemal complexes.

Рис. 5. Схема сперматогенеза тихоокеанской устрицы Crassostrea gigas.

A - сперматогоний; В — первичный сперматоцит; C — вторичный сперматоцит со жгутиком; С' — вторичный сперматоцит с внутренней аксонемой; D - ранняя сперматида со жгутиком; D' - ранняя сперматида с внутренней аксонемой; Е - средняя сперматида со жгутиком; Е' - средняя сперматида с внутренней аксонемой; $\mathrm{F}$ - поздняя сперматида; $\mathrm{G}$ - поздняя сперматида; $\mathrm{H}$ - сперматозоид. Обозначения: $a$ - акросома, $a r-$ осевой стержень, $a v$ - акросомная гранула, $d c$ - дистальная центриоль, $f$ - жгутик, $G$ - диктиосомы комплекса Гольджи, $i a x$ - внутриклеточная аксонема, $k$ - пузырек, $m$ - митохондрия, $n-$ ядро, $n l$ - нуаж, представленный крупным герминальным «тельцем», $n 2$ - нуаж, представленный скоплением мелких гранул, $n l$ - углубления в ядре, $p c$ - проксимальная центриоль, $p v-$ проакросомная гранула, $r e r-$ шероховатый эндоплазматический ретикулум, sas - субакросомный материал, snc - синаптонемальный комплекс. 


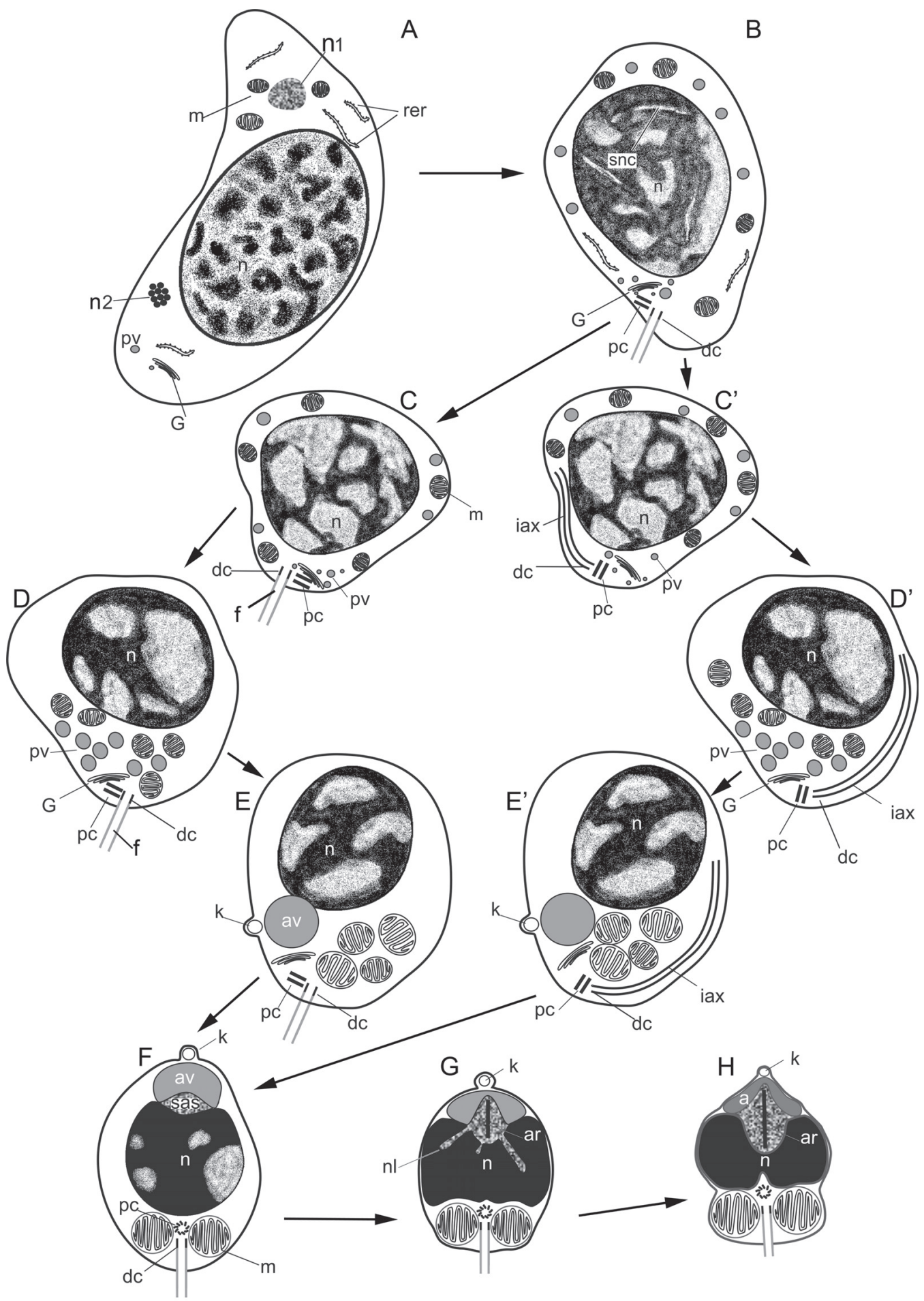


of subacrosomal substance formation have never been discussed. Based on the present data we suggest that the formation of subacrosomal material in C. gigas is connected with the appearance of intranuclear lacunae (Fig. 5G). In the course of spermiogenesis these lacunae were often found to release their content into subacrosomal space and this mechanism seems to relate to subacrosomal material formation. The electron-lucent intranuclear lacunae were noticed in Saccostrea commercialis (Healy, Lester, 1991), Tectura testudinalis (Buckland-Nicks, Howley, 1997) and Tridacna maxima (Keys, Healy, 1999) but authors did not discuss their origin. It seems rather possible that the performance of electron-lucent nuclear lacunae is related to a poorly known mechanism of subacrosomal material formation, which should be better studied not only in Ostreidae but in other invertebrates as well.

We observed numerous mitochondria concentrated in the centriolar region starting from the stage of early spermatid, thus forming a sperm midpiece. There were five to six mitochondria in the middle and late spermatids, but in the spermatozoa only four mitochondria were always present around the basal part of the tail. The reduction of mitochondria in spermatids occurs probably due to their fusion, as in other mollusks studied (Hodgson, Bernard, 1986; Hodgson et al., 1987). The number of mitochondria in the spermatozoa seems to be characteristic for mollusks at a family or even superfamily level (Healy, 1995). Oyster species typically have four mitochondria in spermatozoa (Bozzo et al., 1993; Sousa, Oliveira, 1994a; Eckelbarger, Davis, 1996; Gwo et al., 1996; Drozdov et al., 2009), but Dong and co-authors (2005) reported different patterns of midpiece organization in diploid and tetraploid individuals of $C$. gigas. In diploid oysters, only four mitochondria were present in mature spermatozoa, while in tetraploid oysters, four mitochondria were present in $44 \%$, five mitochondria in $53 \%$, and six mitochondria were present in 3\% of sperm. Five mitochondria were also observed in the midpiece of some spermatozoa of $C$. virginica (Eckelbarger, Davis, 1996) but taking into account large amount of cytoplasm seen on the figure, those cells might be premature and mitochondria may later fuse and thus decrease in number. Anyway, whether this number of mitochondria was a local deviation from normal condition remains unknown.

Dimensional data of spermatogenic cells of oysters are very scanty. We have found only sizes of spermatogonia and spermatocytes as whole cells for C. virginica (Eckelbarger, Davis, 1996) and sizes of just spermatogonial and spermatocytal nuclei for Atlantic C. gigas (Franco et al., 2008). An oval form of spermatogonial and spermatocytal nuclei (especially in primary spermatocytes) makes measuring difficult; that is why for detailed description it would be better to give two sizes: along short and long axes. The sizes of spermatogonia and spermatocytes of Atlantic and the Pacific $C$. gigas are likely to be similar, but we think that this feature is not enough informative because it may depend on the peculiarities of measure techniques and fixation procedures.

Ultrastructural studies of sperm morphology in C. gigas from different geographical regions reported different sizes of sperm parts (Table 1). But whether sperm size differences in various populations of the $C$. gigas are caused by approximate measurements or they reflect real differences in sperm size remains unclear. Additionally, males of many species can simultaneously produce two or more sperm types ("sperm heteromorphism"). Besides, spermatozoa could have identical shape but differ from each other by their lengths only (short or long) (Snook, 1998). Moreover, as it was shown for the sea urchin Strongylocentrotus droebachiensis the spermatozoa may have different sizes in remote populations of the same species (Marks et al., 2008). We think that focused study of various ostreids sperm collected by similar methods are required to make a final conclusion concerned sperm uniformity existence or absence in Ostreidae.

Thus, the developing spermatogenic cells of the Pacific population of $C$. gigas have some characteristic features such as two kinds of nuage-like material in the spermatogonia, intra- 
Table 1. Dimensions of spermatozoa of the Pacific oyster Crassostrea gigas as reported from different regions of the Oceans.

Таблица 1. Размерные характеристики сперматозоидов тихоокеанской устрицы Crassostrea gigas из различных регионов Мирового океана.

\begin{tabular}{|l|c|c|c|c|}
\hline \multicolumn{1}{|c|}{ Region } & $\begin{array}{c}\text { Head length, } \\
\boldsymbol{\mu m}\end{array}$ & $\begin{array}{c}\text { Head width, } \\
\boldsymbol{\mu m}\end{array}$ & Length/width & Reference \\
\hline Taiwan & $\sim 1.93^{*}$ & $\sim 1.55$ & $\sim 1.25^{*}$ & Gwo et al., 1996 \\
\hline Pacific coast of the USA & $2.61^{* *}$ & $2.32^{* *}$ & $1.12^{* *}$ & Dong et al., 2005 \\
\hline Atlantic Spain & - & $\sim 2$ & - & Bozzo et al., 1993 \\
\hline $\begin{array}{l}\text { Pacific coast of Honshu } \\
\text { Island, Japan }\end{array}$ & $2.46 \pm 0.06$ & $2.29 \pm 0.04$ & 1.07 & Komaru et al., 1994 \\
\hline $\begin{array}{l}\text { North-western part of } \\
\text { the Sea of Japan, Russia }\end{array}$ & $2.80^{*}$ & 2.50 & 1.12 & Drozdov et al., 2009 \\
\hline $\begin{array}{l}\text { North-western part of } \\
\text { the Sea of Japan, Russia }\end{array}$ & 2.51 & 2.12 & 1.18 & Present study \\
\hline
\end{tabular}

* sperm head length is calculated by us as a sum of the acrosome, nucleus and mitochondrion dimensions (according to Dong et al., 2005);

** only for fixed spermatozoa of diploid oysters;

- no data.

* длина головки подсчитана нами, как сумма размеров акросомы, ядра и митохондрий (по Dong et al.,, 2005);

** только для фиксированных сперматозоидов диплоидных устриц;

- нет данных.

cellular axonemes, and the apical knob of acrosomal vesicle which is typical for spermatids and sperm. The presence of these characters emphasizes speciality of the $C$. gigas spermatogenesis (Fig. 5A-H) in comparison with other oyster species studied. Since some of these characters have not been described in the Atlantic population of the $C$. gigas and in the other oyster species, it is rather possible that they have not attracted the author's attention and probably might be found by reinvestigation. The pattern of $C$. gigas spermatogenesis which includes many ultrastructural features may be used in future comparative studies of sperm development in Ostreidae and other mollusks.

\section{Acknowledgments}

Our sincere gratitude is due to Yuri Yakovlev for his useful advices, and Denis Fomin and Julia Zograf for their technical assistance. Financial support was provided by the Russian Foundation for Basic Research (RFBR 05-0490589) through the Taiwan-Russian Joint Research Cooperative Programme (Contract RP05B11), RFBR (Projects \#\# 09-04-98562, 09-04-98540, 09-04-01235, 09-04-01326-a),
Far East Branch of the Russian Academy of Sciences (FEB RAS Project \# 09-III-A-06-215, \# 09-III-D-06-300), and the Russian Science Support Foundation.

\section{References}

Afzelius B.A. 1984. Spermiogenesis in Myzostomum cirriferum (Annelida, Myzostomida) // Vidensk Medd Dan Naturhist Foren Khobenhavn.Vol.145. P.11-21.

Àu D.W.T., Reunov A.A., Wu R.S.S. 1998. Four lines of spermatid development and dimorphic spermatozoa in the sea urchin Anthocidaris crassispina (Echinodermata, Echinoida) // Zoomorphology. Vol.118. P.159-168.

Au D.W.T., Reunov A.A., Wu R.S.S. 1999. Two patterns of flagellum development during spermiogenesis of Diadema setosum and Salmacis bicolor (Echinodermata: Echinoidea) // Invertebrate Reproduction and Development. Vol.35. P.147-150.

Bozzo M.G., Ribes E., Sagrista E., Poquet M., Durfort M. 1993. Fine structure of the spermatozoa of Crassostrea gigas (Mollusca, Bivalvia) // Molecular Reproduction and Development. Vol.34. P.206-211.

Brandriff B., Moy G.W., Vacguier V.D. 1978. Isolation of sperm bindin from oyster (Crassostrea gigas) // Gamete Research. Vol.1. P. 89-99.

Buckland-Nicks J., Howley B. 1997. Spermatogenesis and sperm structure in relation to early events of fertilization in the Limpet Tectura testudinalis (Miiller, 1776) // Biological Bulletin. Vol.193. P.306-319. 
Daniels E.W., Longwell A.C., Mcniff J.M. 1971. Ultrastructure of spermatozoa from the American oyster Crassostrea virginica // Transactions of the American Microscopical Society. Vol.90. P. 275-282.

Dong Q., Huan G.C., Tiersch T.R. 2005. Spermatozoal ultrastructure of diploid and tetraploid Pacific oysters // Aquaculture. Vol.249. P.487-496.

Drozdov A.L., Sharina S.N., Tyurin S.A. 2009. Sperm ultrastructure in representatives of six bivalve families from Peter the Great Bay, Sea of Japan // Russian Journal of Marine Biology. Vol.35. P.236-241.

Eckelbarger K.J., Bieler R., Mikkelsen P.M. 1990. Ultrastructure of sperm development in mature sperm morphology in three species of commensal bivalves (Mollusca: Galeommatoidea) // Journal of Morphology. Vol.205. P.63-75.

Eckelbarger K.J., Davis C.V. 1996. Ultrastructure of the gonad and gametogenesis in the eastern oyster, Crassostrea virginica. II. Testis and spermatogenesis // Marine Biology. Vol.127. P.89-96.

Eckelbarger K.J., Young G.M., Cameron J. 1989. Ultrastructure and development of dimorphic sperm in the abyssal echinoid Phrissocystis multispina (Echinodermata: Echinoidea): implication for deep sea reproductive biology // Biological Bulletin. Vol.176. P.257-271.

Eddy E.M. 1975. Germ plasm and the differentiation of the germ cell line // International Review of Cytology. Vol.43. P.229-280.

Erkan M., Sousa M. 2001. Ultrastructure of spermatogenesis in Cerastoderma glaucum (Cardiacea) and Spisula subtruncata (Mactracea) // Invertebrate Reproduction \& Development. Vol.40. P.227-238.

Erkan M., Sousa M. 2002. Fine structural study of the spermatogenic cycle in Pitar rudis and Chamelea gallina (Mollusca, Bivalvia, Veneridae) // Tissue \& Cell. Vol.34. P.262-272.

Extavour C., Akam M. 2003. Mechanisms of germ cell specification across the metazoans: epigenesis and preformation // Development. Vol.130. P.5869-5884.

Franco A., Berthelin C.H., Goux D., Sourdaine P., Mathieu M. 2008. Fine structure of the early stages of spermatogenesis in the Pacific oyster, Crassostrea gigas (Mollusca, Bivalvia) // Tissue and Cell. Vol.40. P.251-260.

Franzén $\AA$. 1956. On spermatogenesis, morphology of the spermatozoon and biology of fertilization among invertebrates // Ibid. Vol.31. P.355-482.

Gwo J.C., Liou C.H., Cheng C.H. 1996. Ultrastructure of the spermatozoa of the Pacific oyster Crassostrea gigas (Mollusca, Bivalvia, Ostreidae) // Journal of Submicroscopic Cytology and Pathology. Vol.28. P.395-400.

Healy J.M. 1995. Sperm ultrastructure in the marine bivalve families Carditidae and Crassatellidae and its bearing on unification of the Crassatelloidea with the Carditoidea // Zoologica Scripta. Vol.24. P.21-28.

Healy J.M., Lester R.J.G. 1991. Sperm ultrastructure in the Australian oyster Saccostrea commercialis (Iredale \& Roughley) (Bivalvia: Osteroidea) // Journal of Molluscan Studies. Vol.57. P.219-224.
Hodgson A.N., Bernard R.T.F. 1986. Ultrastructure of the sperm and spermatogenesis of three species of Mytilidae (Mollusca: Bivalvia) // Gamete Research. Vol.15. P.123-135.

Hodgson A.N., De Villiers C.J., Bernard R.T.F. 1987. Comparative spermatology of two morphologically similar species of Solen (Mollusca: Bivalvia) // South African Journal of Zoology. Vol.22. P.264-268.

Hodgson A.N., Heller J., Bernard R.T. 1990. Ultrastructure of the sperm and spermatogenesis in five South African species of the trochid genus Oxystele (Mollusca, Prosobranchia) // Molecular Reproduction and Development. Vol.25. P.263-71.

Ikenishi K. 1998. Germ plasm in Caenorhabditis elegans, Drosophila and Xenopus // Development Growth \& Differentiation. Vol.40. P.1-10.

Keys J.L., Healy J.M. 1999. Sperm ultrastructure of the giant clam Tridacna maxima (Tridacnidae: Bivalvia: Mollusca) from the Great Barrier Reef // Marine Biology. Vol.135. P.41-46.

Komaru A., Konishi K., Wada K.T. 1994. Ultrastructure of spermatozoa from induced triploid Pacific oyster, Crassostrea gigas // Aquaculture. Vol.123. P. 217-222.

Li Q., Osada M., Kashihara M., Hirohashi K., Kijima A. 2000. Effect of ultraviolet irradiation on the genetical inactivation and morphological features of sperm of the Pacific oyster Crassostrea gigas // Fisheries Science. Vol.66. P.91-96.

Marks J.A., Biermann C.H., Eanes W.F., Kryvi H. 2008. Sperm polymorphism within the sea urchin Strongylocentrotus droebachiensis: divergence between Pacific and Atlantic Oceans // Biological Bulletin. Vol.215. P.115-125.

O Foighil D. 1989. Role of spermatozeugmata in the spawning ecology of the brooding oyster Ostrea edulis // Gamete Research. Vol. 24. P.219-228.

Osanai K., Kyozuka K. 1982. Cross fertilization between sea urchin eggs and oyster spermatozoa // Gamete Research. Vol.5. P.49-60.

Reunov A.A., Au D.T.W., Wu R.S.S. 1999. Spermatogenesis of the green-lipped mussel Perna viridus with dual patterns of acrosome and tail development in spermatids // Helgoland Marine Research. Vol.53. P.62-69.

Reunov A.A., Drozdov A.L. 1987. [Spermatogenesis and ultrastructure of spermatozoa of the mussel Mytilus coruscus] // Tsitologiya. Vol.29. P.260-266 [in Russian].

Reunov A.A., Hodgson A.N. 1994. Ultrastructure of the spermatozoa of five species of South African bivalves (Mollusca), and an examination of early spermatogenesis // Journal of Morphology. Vol.219. P. 275-283.

Retzius G. 1904. Zur kenntnis der spermien der Evertebraten // Biologische Untersuchungen. N.F. P.1-32.

Ruesink J.L., Lenihan H.S., Trimble A.C., Heiman K.W., Micheli F., Byers J.E., Kay M.C. 2005. Introduction of non-native oysters: ecosystem effect and restoration implications // Annual Review of Ecology, Evolution, and Systematics. Vol.36. P.643-89. 
Snook R. 1998. The risk of sperm competition and the evolution of sperm heteromorphism //Animal Behaviour. Vol.56. P.1497-1507.

Sousa M., Corral L., Azevedo C. 1989. Ultrastructural and cytochemical study of spermatogenesis in Scrobicularia plana (Mollusca: Bivalvia) // Gamete Research. Vol.24. P.393-401.

Sousa M., Oliveira E. 1994a. An ultrastructural study of Crassostrea angulata (Mollusca, Bivalvia) spermatogenesis // Marine Biology. Vol.120. P.545-551.
Sousa M., Oliveira E. 1994b. An ultrastructural study of spermatogenesis in Helcion pellucidus (Gastropoda, Prosobranchia) // Invertebrate Reproduction \& Development. Vol.26. P.119-126.

Suwanjarat J. 1999. Ultrastructure of the spermatogenesis of the cockle Anadara granosa L. (Bivalvia: Arcidae) // Helgoland Marine Research. Vol.53. P.85-91.

Responsible editors: V.V. Yushin, E.N. Temereva 